\title{
An Early Chart of Tasmania
}

\section{Author(s): William Foster}

Source: The Geographical Journal, Vol. 37, No. 5 (May, 1911), pp. 550-551

Published by: geographicalj

Stable URL: http://www.jstor.org/stable/1778280

Accessed: 14-04-2016 22:20 UTC

\section{Your use of the JSTOR archive indicates your acceptance of the Terms \& Conditions of Use, available at}

http://about.jstor.org/terms

JSTOR is a not-for-profit service that helps scholars, researchers, and students discover, use, and build upon a wide range of content in a trusted digital archive. We use information technology and tools to increase productivity and facilitate new forms of scholarship. For more information about JSTOR, please contact support@jstor.org.

The Royal Geographical Society (with the Institute of British Geographers), Wiley are collaborating with JSTOR to digitize, preserve and extend access to The Geographical Journal 
has written an article about some others to prove that they are Boga graves ; but neither of these conclusions appear acceptable to me. Names such as Assarema Derheib, "the Seven Buildings," or Adarminish, "the Red Tombs," show that there has been a complete break in tradition between their constructors and the present "Bedaue"-speaking nomads. There is an enormous cemetery close by in Khor Gamarota, containing graves of various types, but for the most part surrounded with upright slabs, and these, though not like the latest form of grave used by the Beni Aamer, are recognized by the present inhabitants as graves, whereas the buildings of Assarema Derheib are variously explained as houses and forts and treasuries ; in other words, they belong to a past as utterly forgotten as do the ruins of Badi. I suggest, therefore, that the whole group reaching from the coast of the Red sea to the neighbourhood of Kasala is to be attributed to an early wave of Mohammedan immigration, before the growth of the principalities of Baza, Taka, and others which arose between the disruption of the southern kingdom of Aloa and the rise of the Sultanate of Sennar, roughly between 1100 and 1500 A.D.

\section{AN EARLY CHART OF TASMANIA.*}

\section{By WILLIAM FOSTER.}

THE fact that the India Office possessed an old manuscript chart, apparently contemporary, of some portion of the new lands discovered by Abel Tasman in his famous voyage of 1642-43 was first made known in Sir George Birdwood's 'Report on the Miscellaneous Old Records of the India Office,' printed in 1879. Some years later, this reference attracted the attention of Mr. A. Mault, of Hobart, who, recognizing that the chart represented the southern coast of Tasmania, made a careful copy of it, and in January, 1892, read a paper on the subject before the Australasian Association for the Advancement of Science. The paper was afterwards printed by the Association in its report of the meeting (p. 408), and a coloured reproduction of Mr. Mault's copy of the chart was given.

Mr. Mault was unable at the time to glean any information regarding the origin of the chart or the means by which it came into the possession of the English East India Company ; but he conjectured that it was either the original or a copy of one made on board the Zeehaan (one of the two ships employed in the voyage), and that it was obtained by some Englishman at Batavia upon the return of the expedition. These suggestions were discussed by Professor Heeres in the essay appended to the sumptuous facsimile of Tasman's journal issued at Amsterdam in 1898, and the conclusion reached was that until further information should be forthcoming it was impossible to say how the drawing originated.

$$
\text { * Map, p. } 588 .
$$


The mystery has now been cleared up; for recently, in examining the India Office records of the time, I found the following passage in a contemporary copy of a letter addressed by the English President and Council at Bantam to the home authorities early in 1644 :-

" The Dutch have lately made a new discovery of the South Land in the latt[itude] of $44 \mathrm{~d}$ [egrees] and their longitude 169, the draught whereof is herewith sent. They relate of a gyantlike kinde of people there, very treacherouse, that tore in peeces lymbemeale [i.e. limb by limb] their merchant, and would have done them further mischeife, had they not betaken them to their shipps. They make mention alsoe of another sort of people about our stature, very white, ruddy, and comely, a people gentle and familiar, with whome, by their owne rellations, they have had some private conference. We are tould that the Dutch Generall [i.e. Governor-General] intends to send thither againe and fortifie, having mett with some thing worth the looking after. They have discovered a second Mauritius, some 80 leagues to the northwards of the other, whose draught [missing] is likewise herewith sent you ; both the one and the other not to be had or procured from them but by extraordinary freindshipp."

The account here given of the voyage is vague, and in some respects inaccurate. This is not surprising, for the Dutch officials would naturally be reticent on the subject, and the narrator was probably obliged to content himself with what could be gleaned from the gossip of the sailors. The conflict with the natives was doubtless that which occurred in "Moordenaars Baai" (New Zealand) ; but no merchant was killed on that occasion, nor were the aggressors "a gyantlike kinde of people." The latter may be a confused reference to the very tall men seen on Three Kings islands.

The document from which the quotation is taken is dated January 10, 1644, and is to be found among the Original Correspondence (No. 1853), while the chart itself is now in volume 4 of the Miscellaneous Marine Records. The latter is reproduced in the present number of the Journal. It is practically identical (save for the omission of names and of the track of the vessels) with Tasman's own map, which has been reproduced by Valentyn, Burney, Heeres, and others. The paper on which it is drawn measures about 15 inches by $12 \frac{3}{4}$, but the chart itself only occupies a space $13 \frac{3}{4}$ inches by $9 \frac{3}{4}$. On the back is written : "A draught of the South Land lately discovered, 1643." The outline has been coloured in green and yellow, and depicts the run of the coast from about Cape Sorell on the west coast to Freycinet peninsula on the east. As already mentioned, Tasman's track is not given; but his anchorage in Marion bay is marked. The longitude, which is reckoned (after the Dutch fashion) from the Peak of Teneriffe, differs somewhat from that adopted by Tasman. This point, however, has been already dealt with by Prof. Heeres. 


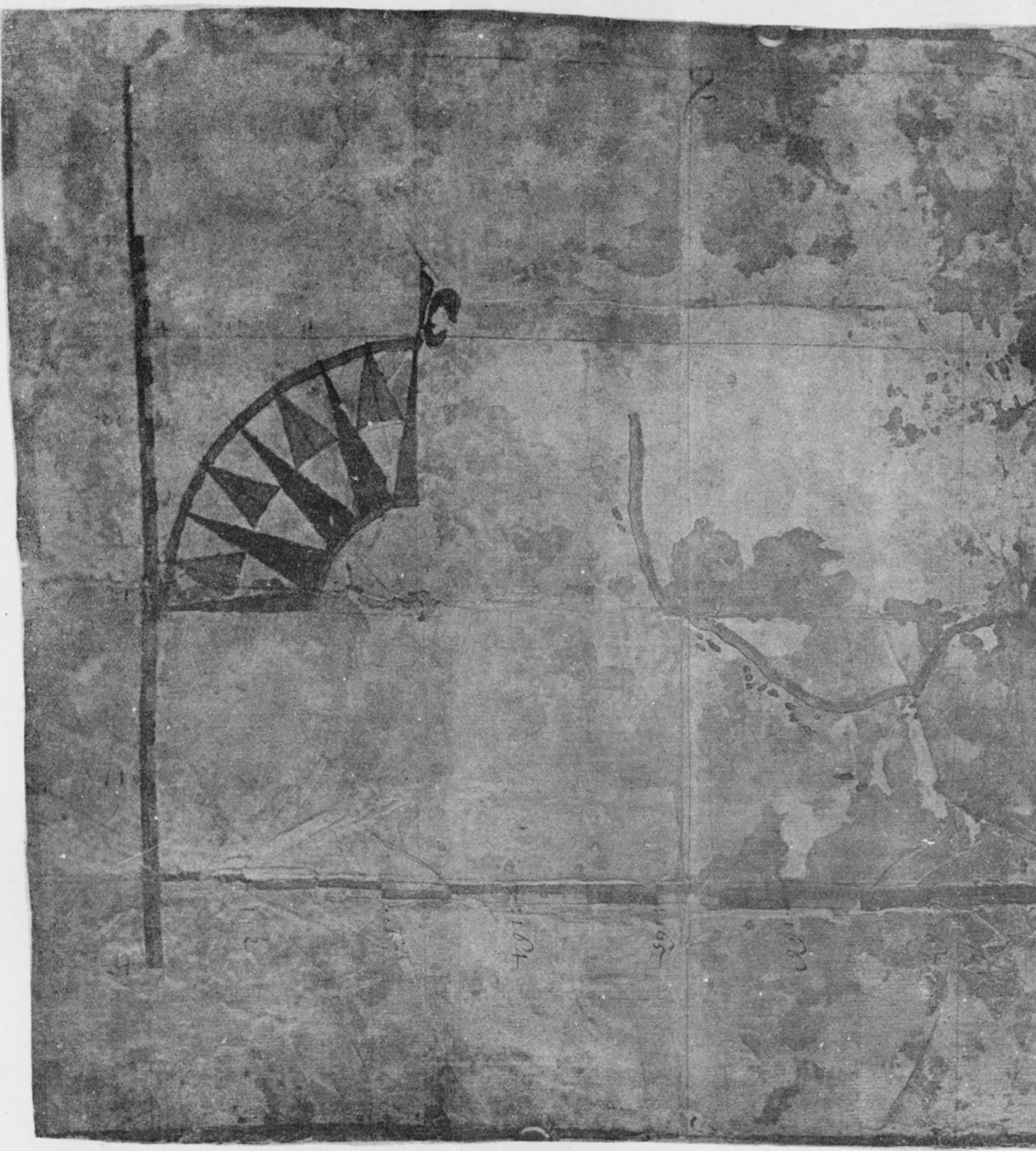

COPY OF TASMAN'S CHART OF TASMANIA, 1643

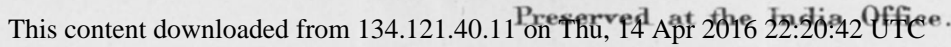

All use subject to http://about.jstor.org/terms 
